Tér és Társadalom 20. évf. 2006/3. 109-116. p.

Tér és Társadalom

XX. évf. 2006

3: $109-158$

KÖNYVJELZÖ

\title{
INDUSZTRIA GYERMEKEI: MAGYAR IPARVÁROSOK A XX. SZÁZADBAN
}

\author{
Tudományos és Közéleti Konferencia \\ (Százhalombatta, 2005. szeptember 27-28.)
}

\section{LUX GÁBOR}

A szocialista fejlesztéspolitika legambiciózusabb projektjei közé tartoztak azok az újonnan telepített vagy éppen alacsonyabb bázisról felfejlesztett iparvárosok, amelyek korukban nem csupán a gazdaság zászlóshajói, hanem egyben a rendszer szimbolikus terei, kísérleti telepei is voltak. Nem csak a gazdasági-politikai irányítás, hanem a városépítészet, a társadalompolitika és a mủvészet korabeli irányzatai is hozzájárultak létrejöttükhöz és kiépülésükhöz. A szimbolikus szerep a rendszerváltáshoz közeledve átalakult. A súlyosbodó válsággal párhuzamosan az új városokat mint a szocializmus kudarcának ékes bizonyítékait kezdték el emlegetni. Egyesek közülüik mély és igen súlyos depresszión estek át (ez különösen a bányászatra és a hagyományos nehéziparra alapozott településekre vonatkozik, ahol a nagyüzemek szinte teljesen leépültek vagy megszủntek), mások iparukat megtartva is válsággal néztek szembe. Mïg a felépítésük utáni évtizedekben föként az volt a kérdés, hogy menynyiben mások ezek a települések, mint a hagyományos városok, ma már azt a kérdést is feltehetjük, hogy mennyiben hasonlók - vagyis sikerült-e beilleszkedniük a magyar városhálózatba, a mesterséges telepítés jegyei ma megkülönböztető sajátosságok-e még. vagy erröl mál nem beszélhetünk?

A Százhalombattán megrendezett tudományos és közéleti konferencián a városok vezetői és szakértői, illetve a regionális tudományok és más tudományterületek képviselöi próbáltak választ adni ezekre a kérdésekre, áttekintve a valaha ,piszkos tizenkettő" néven ismert városcsoport múltjăt, jelenét és jövőjét. A konferenciát a százhalombattai „Matrica” Múzeum és az 1956-os Intézet rendezte. Ugyanekkor került megnyitásra az a vándorkiállítás, amely az egyik fỏ rendezö, Germuska Pál könyvében (Germuska Pál [2004] Indusztria büvöletében. Budapest, 1956-os Intézet, 2004) is megjelent gazdag képanyagra és az elmúlt korszak tárgyi kultúrájára alapozva mutatja be a szocialista városok mindennapjait. Az elsô nap elöadásait az egyes városok bemutatkozásai tették ki, míg a második napon jutott idő a tudományos elöadásokra, rövid városnézésre és a konferencia lezárására.

Vicze Magdolna, a „Matrica” Múzeum igazgatójának rövid megnyitója után Benedek László, a vendéglátó város polgármestere tartotta meg előadását. Mint rámutatott, a városfejlesztés második hullámában, a petrolkémia és energetika alapjain 
Tér és Társadalom 20. évf. 2006/3. 109-116. p.

fejlesztett Százhalombatta átalakulásában nagy szerepet játszott az, hogy a városvezetés aktívan kereste a gazdasági diverzifikáció és az önkormányzat szerepvállalásának lehetöségeit. A valaha 4600, ma 1700 főt foglalkoztató két nagyvállalat helyét részben átvette a város ipari parkja; ebben arra törekednek, hogy minél inkább elterjedjenek a magas hozzáadott értéket előállító, képzett munkaeröt foglalkoztató tevékenységek. Egyúttal említést érdemel Százhalombatta annak idején túltervezett közintézményhálózata, vagyis egészségügyi és oktatási létesítményei.' A valamikor egyfunkciós város ma térségi vonzáskörzeti kapcsolatokat alakít ki, és a régión belül magasszintủ szolgáltatóként kíván föllépni.

Oroszlányról Székely Antal alpolgármester tartott elỏadást. A város iparát a barnaszénre alapozták (már a II. világháború elött folyt kitermelés), erre települt a közepes méretü, Magyarország villamosenergia szükségletének 5\%-át biztosító erömü. A rendszerváltás után a bányát és az erỏmủvet összevonták, de a vállalat állami tulajdonban maradt, és bezárására a létszám mintegy kétharmadát érintô leépítések után sem került sor. Az ipari park itt is sikeresnek tekinthetö 2000 emberrel, de az alacsony tudást igénylő betanított munka és a magas tudásigényü tevékenységek közötti rés tágulásával elengedhetetlen a képzési struktúra korszerüsítése. A város társadalma máig megtartotta kedvezö korfáját, $s$ akár Százhalombatta, Oroszlány is fejlett intézményhálózattal rendelkezik, építetı környezete is kedvezỏnek mondható.

Kiss Vendel történész Tatabánya múltjáról számolt be. Tatabánya bányászatát a Magyar Általános Köszénbánya Rt. (MÁK) teremtette meg, s megindult egy amerikai típusú telep felépítése is: az eredeti 2500 föről már az I. világháború előtt 7000 före emelkedett a lakosság és 3 millió tonnára az éves kitermelés. 1920 után szénre és energiára új, korszerü ipart telepítettek (szénlepárlás, karbidgyártás, alumíniumkohászat), s tovább bővült a lakásállomány. Így Tatabánya már a szocializmus előtt elnyerte városi karakterét, fejlett tercier szektor épült ki a lakosság kiszolgálására. Az 1950-es évek fejlödése tehát csak az elözmények felnagyításának tekinthetö. A szénvagyon kimerülése, a gazdasági szerkezetváltás elmaradása Tatabányát is válságba sodorja: már 1987-ben bekövetkezett a vállalati csőd, ami után a szénbányászatot teljesen felszámolták.

Várpalota szerkezetváltásáról tartott elöadást Pál Károly városmenedzser. Várpalota a Dunántúli-középhegység több más településéhez hasonlóan régi alapítású ipari település, valamikor több lábon álló, igen kiterjedt kitermelö- és nehéziparral. A szénbányászatot a magas fokú gépesítés jellemezte, ${ }^{2}$ a szenet az Inotai Höerömü, a közepes méretú alumíniumkohó és a Péti Nitrogénművek használták fel. A rendszerváltás után 1995-ben felhagytak a szénbányászattall, 2000-ben bezárt a höerőmü, és 2006-tól az alumíniumkohó is beszünteti múködését. Tehát Várpalota és környéke gazdasági bázisa erösen összezsugorodott. egyedül a privatizált Nitrogénmnúvekben maradt fenn a nehézipar: ma ez a térségi fö munkaadó, célja Közép-Európa legnagyobb vegyi üzemévé válni. A városban két ipari park is müködik, ma még alàcsony kihasználtsággal.

Dunaújváros képviseletében Rohonczi Sándor gazdasági bizottsági elnök és Fehérvári Tamás számolt be a település terveiröl. Dunaúijváros Magyarország leg- 
Tér és Társadalom 20. évf. 2006/3. 109-158. p.

jelentősebb szocialista városa volt, s mivel városhiányos térségben jött létre, mára egy 150 ezer fỏs vonzáskörzetet kiszolgáló középvárossá emelkedett. Mai elképzeléseiben hídszerepét, négy régió felé való nyitottságát hangsúlyozza. A 2004-ben privatizált vasmú mellett több országos jelentőségü cég (Ferrobeton, Dunapack, Dunaforg) telephelye, logisztikai központ. 'Intézményei kihasználására kistérségi együttmúködést kötött, mára ipara mellett iskolaváros is, ötezer fós főiskolával. Az utóbbi idöben megnött az érdeklödés épített öröksége iránt; városképe átlátható, szellős és müvészetében is figyelemreméltó.

Komló alpolgármestere, Szakács László kiemelte, hogy Komló néhai „mesés” gazdagsága után nagyon mély válságot élt át, s csak 2001 után kezdődött meg az intenzív szerekezetváltási politika. Komoly gondot okoz ma is, hogy az ipart az egyetlen sík területre, a város szívébe telepítették, míg a bányák a szélén helyezkedtek el. A leépuilt létesítmények helyén kialakitott ipari parkban kis- és középvállalatok jelentek meg, ami egyben komoly szemléletváltást is jelent a nagyvállalati múlt után. Bár sokak szemében Komló „halott város”, mára megmutatkoznak erósségei is: a környezetszennyezés visszaesésének köszönhetően jelentősen javult élhetősége (a szétszórt városrészeket erdők határolják), a több lábon álló gazdaság kihasználhatja a Pécs mellett megépült repülötér lehetőségeit, jelentősek a város kistérségi kapcsolatai, kulturális rendezvényei.

Mádai Ferenc alpolgármester és Paulics lstván oktatási irodavezető Ajka átalakult gazdaságáról és demográfiai helyzetéról tartott beszámolót. Várpalotához hasonlóan a múltban Ajka is több iparvállalatra alapozott település volt, s ezek átalakulása más-más kifutási idő alatt következett be. A szénbánya és a höerömü esetén biztosítani lehetett a fokozatos átmenetet és időben gondoskodni a munkaerő elhelyezéséról és nyugdíjazásáról. A valaha szovjet-magyar kooperációban ủzemelö timföldgyártás teljesítménye felére zsugorodott; az alapanyag feldolgozását egy helyi öntöde végzi. Végül a Videoton főleg női munkaeröt alkalmazó gyára teljesen összeomlott és megszünt. Elmondható, hogy a város mára részben talpraállt, fö feladatának a munkahelyteremtést és a népességmegtartó erö javítását tartja.

Bárdos Balázs alpolgármester az Ózdról készült rövidfilm bemutatása után kiemelte, hogy a nehézipari válságot legkorábban és talán legerősebben megszenvedő városnak hazai példák hiányában magának kellett kidolgoznia a válságkezelés megoldásait. Ózd néhai ipara szinte semmivé zsugorodott, kohászata ma már csak 4-500 föt foglalkoztat. Így ma az elektronikai iparra (General Electric) támaszkodik, és a rendelkezésére álló barnamezős területek rekultiválásával ipari profilú kisvállalatok letelepedését támogatja.

Az ülés végén Csurák Zsuzsanna történész hangsúlyozta, hogy Kazincbarcika nagyméretü vegyipari komplexuma a csökkenö foglalkoztatás dacára sikeresen véghezvitte a szerkezetváltást, ezzel térségi szerepét is megtartva. A két ipari park egyikének profilja is szorosan kapcsolódik a vállalat profiljához. Kazincbarcika társadalmában erősebb volt az elöregedés más szocialista városoknál, korfája ma már nem sokban tér el az országos átlagtól. Továbbra is megoldatlan probléma a nagyszámú cigány lakosság integrácjójának elmaradása és a ma is magas munkanélküliség. 
A konferencia második napján tartották meg a tudományos elöadásokat. Nyitó elöadásában Germuska Pál az új városok - szocialista városok fogalmának tisztázására, e városok „rendszertani” besorolására tett kísérletet. A szocializmus városfejlesztése a rendszer propagandaeszköze volt, amelyben eleinte nagyon erős kánon érvényesült, de késöbb ez a kánon részben vagy egészében felbomlott, a fogalom pedig zavarossá vált. Ennek ellenére megragadhatók azok a jellegzetességek, amelyek megkülönböztették-megkülönböztetik őket mind a történelmi városállománytól, mind a Nyugat-Európában és Észak-Amerikában kialakított új városok többségétől. A több forrás felhasználásával definiált városfogalom tényezỏiként fontos megemlíteni a fejlesztéspolitikában és az elosztásban elfoglalt kiemelt szerepet, az urbanizálatlan térségekbe irányuló iparosítás városi funkciókat ,„vonzó” hatását, az ipari foglalkoztatás túlsúlyát és vállalati homogenitását (amely egyben a városi társadalmat is egyöntetủbbé teszi, mint más településeken), illetve a modem városépítészeti elvek fokozott érvényesülését, amelyek azonban pénz hiányában csak részlegesen valósulhattak meg, és sok helyen maradtak torzóban. E kritériumok alapján Magyarországon ma tizenegy telepưlés sorolható a szocialista városok körébe.

Beluszky Pál elöadásában kiegészítette Germuska Pál állításait. Az iparvárosok a 20. század során jelentős szerepet játszottak a magyar városodásban, de az ipari funkciók túlsúlya önmigában még nem bizonyult városképző elemnek. Csak a földrajzi munkamegosztásba való bekapcsolódás, a városi javak cseréje tehet egy települést várossá. Ebben az összefüggésben sokkal egyértelmübb a hagyományos kézmüipar várositó szerepe, mint a nehéziparé. ami akár város hiányában is letelepíthetö, munkaerőigényét ipari községek. munkástelepek is kiszolgálhatják. Egyes esetekben mégis bekövetkezik a városodás: az ipar vonzotta népességtömörülés, a beruházások infrastruktúra- és intézményigénye már elösegítheti a tiszta városi funkciók megtelepedését, majd ezt követöen a térségi-vonzáskörzeti kapcsolatok kiépülését. A magyar városodásban a gyáripar csak az 1890-es évektöl tölt be jelentős szerepet. Létrehozott-fejlesztett tradicionális városokat is, de már ekkor megjelentek olyan, tisztán ipari települések (Salgótarján, Resica, részben Diósgyör, később Ózd, Diósgyör. Tatabánya, Ajka és Várpalota), amelyek a szocialista városok elöképeinek is tekinthetök, és sok tekintetben (szervetlen fejlődés, nagyberuházásokhoz való kötődés, a polgárság gyengesége) hasonlítanak hozzájuk. Az iparvárosok beilleszkedése a városhálózatba leggyorsabban ott következett be, ahol 1945 után megyeszékhellyé nyilvánították öket, illetve nem voltak környékükön városi elözmények. Volt példa arra is, hogy az új városok korábbi településeket „győztek le", átvéve központi szerepkörüket és városi funkcióikat. A rendszerváltás utáni válság újraértékelte az iparvárosok jelentöségét; többségük ma kitüntetett szerepét elvesztve kisvárosként képes bekapcsolódni a területi munkamegosztásba.

Szirmai Viktória Nyugat- és Közép-Kelet-Európa „csinált” városait hasonlította össze. Felhívta a figyelmet arra, hogy a párhuzamok csak bizonyos dimenziókban vonhatók meg (ilyenek például a kormány szerepe létrejöttükben és a városépítészeti kísérletezés), de a döntöen tehermentesítö, a lakáshiány enyhítésére szolgáló nyugati új városok nem azonosíthatók a keleti blokk ipari településeivel, amelyek egyben 
területfejlesztési eszközök, a gazdasági utolérési törekvések bázisai is voltak. Hasonlóan keleti társaikhoz, a nyugati új városok is átélték a maguk részleges kudarcát, válságát: eredetileg kijelölt népességszámukat jelentősen túllépték, ráadásul nem valósult meg bennük a lakó- és munkahely kívánt egysége, továbbra is a közeli nagyvárosokhoz kötödött a lakosság. Hasonlóan sikertelen volt a közösségi terek kialakítását megcélzó törekvés; jórészt üresen és kihasználatianul maradtak, akárcsak a városi intézmények. Az 1990-es években mégis megnött a népszerüségük. $\mathrm{Az}$ új városok alternatívát jelenthetnek a szuburbanizáció visszás jelenségeivel szemben, kevésbé jelentkeznek bennük a társadalmi problémák, és mégindult közeledésük a hagyományos városok gazdaságához, illetve társadalmához.

Barta Györgyi azt a kérdést vetette fel, hogy egyáltalán léteztek-e szocialista városok? A fogalmat a tudomány az újonnan épült városokra alkalmazza, de a ,szocialista" tartalom mindvégig utópikus terv maradt. Létesítésüket, különösen a Szovjetunióban. részben a háború utáni újjáépités igényei, részben (és döntöen) gazdasági szempontok indokolták, nem a településhálózat fejlesztésének szükségletei: ez inkább csak kedvező egybeesés. A hagyományos városoktól való eltérésük különösen szembetủnö a jellegzetes, nagyvonalú területhasználatban (ennek oka az ingatlanpiac hiánya), ám mủködésük már sokkal kevésbé divergens. Nem is ,szocialista”, hanem inkább ,szocializált" városokról volna érdemes beszélni, ahol a köztulajdon dominanciája, a kommunista párt erös közéleti monopóliuma és a magántulajdonellenesség, a Kornai által leírt bürokratikus koordináció túlsúlya a fö különbségképzö tényezö. Gazdasági szerkezetük rendszerspecifikus elemként értelmezhetö, hiszen kiemelt szerepüket a bányászat, valamint a nehéz- és hadiipar az állami fejlesztéspolitika preferencia-sorrendjében elfoglalt föhelyének köszönhették. Mindezek a különbségek azonban nem teszik indokolttá a ,szocialista város” fogalmának alkalmazását, helyesebb volna újonnan iparosult városoknak nevezni öket.

Az elöadások elsö csoportját szakmai vita követte. Bárdos Balízs a városok helyének kijelölésében felhívta a figyelmet a müszaki meghatározottság eddig még nem eléggé tisztázott jelentőségére. A megjegyzéssel Germuska Pál is egyetértett: rámutatott, hogy gyakran a müszaki szakemberek döntéseit „öntötték nyakon” ideológiai mázzal: a korábbi feltételezéseknél sokkal nagyobb szerepe lehetett egy tudományos-szakmai elit döntéseinek, mint akár a politikai föszereplöknek. Szirmai Viktória azt is kiemelte, hogy a müszaki döntések olyan mértékben kerültek túlsúlyba, hogy a társadalmi szempontokra egyáltalán nem figyeltek oda, ami ma is érezteti hatását. Barta Györgyi a városok ma eltérỏ sikerességét elemezve úgy értékelte, hogy az eredeti ipari tevékenységek jellege (bányászat-kohászat, vs. „modernebb" ipar) mellett az ágazati kapcsolódások erössége, megléte sem hagyható figyelmen kívül. Továbbá fölhívta rá a fịgyelmet, hogy a technológia nem determinálta egyértelmüen a várostelepítés helyét: az országban hatalmas keresztszállítási rendszerek múiködtek, s a kötött számú iparvállalat telephelyválasztását politikai döntések (pl. kihelyezési, dekoncentrációs törekvések) is nagymértékben befolyásolták. S-ékely Antal több járulékos tényezővel egészítette ki az iparvárosok eltéréseit: közéletükben nagyon erös volt a szocialista párt, míg intézményeik, kulturális 
életük patronálásában főszerep hárult az iparvállalatokra. Más városoknál erösebb törekvések irányultak a széleskörü közmüvelődés megteremtésére, a „szocialista életmód" kialakítására. A vita végén Beluszky Pál kiemelte, hogy bár nincsenek átfogó értékelések a szocialista városok fejlesztéspolitikájáról, a jövőben sokkal nagyobb szerepet kaphat a városi szerepkör erösítése, a területi szolgáltató szerep következetes kialakítása. Ezzel az iránnyal érdemes volna többet foglalkozni.

$\mathrm{Az}$ ülés második felében föként mủvészeti-építészeti előadások kaptak helyet. Prakfalvi György a szocialista városok építészetéröl szólva fontosnak tartotta megkülönböztetni a szocreált (ez a közvélekedéssel ellentétben neın a Kádár-kor stílusa, hanem egy hazánkban csupán 1951-től 1954-ig élő irányzat) a panelépítészettôl. Előbbi a két világháború közötti irányzatokat magába olvasztva és a hazai sajátosságokat is figyelembevéve modern, élhető lakókörnyezetcket kívánt teremteni, várostervezése „dezurbanista”, szomszédsági egységeket és nagy közösségi tereket létesít. A hatvanas évek tömeges panelépítése ezzel szemben nem is tekinthetö valódi értelemben vett modern építészetnek: tervezésükben az olcsóság-tömeges gyárthatóság és a gyors megépíthetőség volt a fö szempont, s nem a lakhatóság. Szerkezetük kötött, mára a divatba jövö sztálinbarokkal ellentétben gépészeti leromlás és gazdaságtalan energiahasznosítás jellemzi öket. Mindemellett ebben az idöszakban is készültek modern épületek, jellegzetes, a szerkezetiséget hangsúlyozó formákkal (kagylóívek, gombaformák), de sokkal kevésbé lakóépületek céljára.

Sümegi György a szocreál képzömüvészetröl tartott előadást. Ezt a stílust, amelyet az elmúlt harminc évben a „forró gyülölet és a hideg undor" övezett, elkezdték újraértékelni és fölfedezni fennmaradt értékeit. Számos mü elpusztult vagy leromlott, és az sem egyértelmü, mi tekinthetö pontosan szocreálnak. A köztéri alkotások ennek csak egy szeletét képezik, de legalább ilyen fontosak a tömegtermelt mindennapi tárgyak, lakásdekorációk és enteriőrök, melyek rekonstrukciója, föltárása ma már gyakran nehéz feladat.

Balpataki Katalin a szocialista városok egyikéről, a vendéglátó Százhalombattáról tartott helytörténeti elöadást. Százhalombatti több falusias részt foglal magában, s egy idöben elindult az üdülöteleppé válás irínyába. Érdekes kiemelni történetében, hogyan változott a történelıni település és az új város kapcsolata: a falu mellett rohamos gyorsasággal építették föl az ideiglenes, majd állandó lakótelepeket, de sokáig a faluban maradtak a közösségi terek és intézmények, amelyek kiszolgálták az érkezőket: még az ünnepi fölvonulásokat is itt tartottík. Csak a várossá válás sorăn „hagyják magára”, amikor elkészülnek az új, nagyméretü szolgáltató intézmények. De így is csak idővel alakulhatott ki a városi identitás és kötődés - bár még ma is gyengének mondható.

Az utolsó elöadás Páli Zsuzsannáé, Fejér megye föépítészéé volt, aki Dunaújváros építészeti örökségének hasznosítási lehetőségeit elemezte. Dunaújváros minden korszaka saját építészeti stílust képvisel: közülük legjellegzetesebb, s ma már védelemre érdemes az „óváros”, ahol a hagyományos városok nyíltteres beépítése helyett lakótömbök által közrefogott, bennfoglalt parkokkal és közintézményekkel színesített városszerkezet jellemző. A városépítészetre vár a kihívás, hogy az örökség- 
védelem szempontjait egyeztesse a mai igényekkel. Így lakások horizontális és vertikális összevonásával új, tágasabb lakóterek kialakítására nyílik lehetöség, míg az utcafrontokon a magánvállalkozások elhelyezése jelent kihívást. A nem erre tervezett utcákban meg kell oldani a parkolás kérdését (ez más hasonló városokban is szorító probléma), miközben a városvezetésnek az újabb építészeti korszakok épületei - a panelházak, a területi „,nagyfogyasztó” családi házak és a lakóparkok problémáira is figyelemmel kell lennie.

A konferenciát Tüske László százhalombattai alpolgármester zárta le, összefoglalva a városokat érintỏ kihívásokat, és kifejezve affölötti örömét, hogy nehézségeik dacára valamennyi város törekedett a talponmaradásra és az új gazdasági lehetőségek kiépítésére. Egyúttal javasolta, hogy a konferencia legyen hagyományteremtő, s a most Százhalombattán megtekinthetö kiállítás vándorlását követve időről időre folytatódjon a városvezetök, valamint a tudományos élet képviselöinek gondolatcseréje, együttmúködése.

\section{Jegyzetek}

'Ennek legföltủnöbb példája a 18000 lakossal reudelkező város 200000 före szabott kórháza.

${ }^{2}$ Itt találták föl a világszerte ma is alkalmazott, a lalakat hidraulikus karokkal támusztó pajzsbiztosítású fejtési módszert.

${ }^{3}$ A logisztikai központ egyik lehetséges allapja a dunai kikötő, amit kiegészít a nagyforgalmú vasútállomás és a jövőben megépülỏ észak-déli Helsinki korridor. 


\section{KÖNYVJELZÖ}

Tér és Társadalom 20. évf. 2006/3. 109-158. p. 